\title{
Kerentanan Sosio-Ekonomi terhadap Paparan Bencana Banjir dan Rob di Pedesaan Pesisir Kabupaten Demak
}

\author{
Iwan Rudiarto ${ }^{1}$ \\ Departemen Perencanaan Wilayah dan Kota \\ Universitas Diponegoro, Semarang, Indonesia
}

\section{Dony Pamungkas}

Departemen Perencanaan Wilayah dan Kota Universitas Diponegoro, Semarang, Indonesia

\section{Hajar Annisa A.}

Departemen Perencanaan Wilayah dan Kota Universitas Diponegoro, Semarang, Indonesia

\section{Khalid Adam \\ Departemen Perencanaan Wilayah dan Kota Universitas Diponegoro, Semarang, Indonesia}

Artikel Masuk : 30 September 2016

Artikel Diterima : 16 November 2016

Tersedia Online : 30 Desember 2016

\begin{abstract}
Abstrak: Bencana alam merupakan suatu atau serangkaian kejadian yang terjadi secara tibatiba ataupun perlahan oleh manusia, alam, atau keduanya. Bencana alam di wilayah pedesaan pesisir tidak hanya berkaitan dengan kondisi wilayah dimana bencana itu terjadi, melainkan juga berkaitan dengan pola kehidupan dan penghidupan masyarakatnya. Di sisi lain, kondisi sosial ekonomi masyarakat pedesaan di pesisir lebih rentan terhadap paparan bencana mengingat ketergantungan yang tinggi terhadap sumber daya pesisir. Penelitian ini bertujuan untuk mengkaji bagaimana kerentanan sosio-ekonomi masyarakat pedesaan di pesisir Kabupaten Demak terhadap paparan bencana banjir dan rob. Kerentanan yang dimaksud dinilai secara spasial pada unit desa yang tersebar di 4 (empat) Kecamatan di wilayah pesisir Demak. Hasil penelitian menunjukkan bahwa sebanyak 33 desa atau sekitar $42 \%$ dari 78 desa yang dikaji terkategori sebagai paling rentan secara sosio-ekonomi. Sementara itu, 45 desa yang lain atau sekitar 58\% terkategori tidak begitu rentan. Dari hasil penelitian yang didapatkan, diperlukan upaya lebih lanjut untuk menangani masyarakat yang terkategori paling rentan tersebut agar dapat lebih tanggap dari dampak bencana banjir dan rob.
\end{abstract}

Kata Kunci: bencana banjir dan rob, kerentanan sosio-ekonomi, masyarakat pesisir pedesaan

\footnotetext{
${ }^{1}$ Korespondensi Penulis: Departemen Perencanaan Wilayah dan Kota, Universitas Diponegoro, Semarang, Indonesia Email: iwan.rudiarto@undip.ac.id / irudiarto@yahoo.com
} 


\title{
154 Kerentanan Sosio-Ekonomi terhadap Paparan Banjir dan Rob di Pedesaan Pesisir Kabupaten Demak
}

\begin{abstract}
Disaster is an event which suddenly or slowly occurs caused by human, nature, or even both. Disaster is not only related to the physical environment where disaster found but also to the livelihood of the community. Coastal rural is vulnerable to the coastal disaster such as flood and tidal flood due to their high dependency on the coastal resources. The vulnerability assessment of the coastal rural is very important in order to identify the level of vulnerability and to recommend crucial strategies for reducing the risk of disaster exposure in the future. This study aims to identify the socio-economic vulnerability in the rural coastal community of Demak Regency. Vulnerability assessment was carried out through a spatial explicit modeling. The results showed that 33 villages equivalent to $42 \%$ out of the total 78 villages were categorized as most vulnerablesocially and economically. The remaining 45 villages accounted for 58\% were less vulnerable. Therefore, efforts on the disaster mitigation are necessary to reducing the exposure impact to the coastal rural community.
\end{abstract}

Keywords: flood and tidal flood disasters, socio-economic vulnerability, coastal rural community

\section{Pendahuluan}

Bencana adalah suatu kejadian/peristiwa atau serangkaian kejadian/peristiwa yang terjadi secara mendadak maupun perlahan yang disebabkan oleh alam, manusia, atau keduanya sehingga dapat berakibat pada pola kehidupan dan penghidupan, gangguan pada sistem pemerintahan, dan kerusakan ekosistem (Sunarto \& Rahayu, 2006). Pada kawasan pesisir bencana yang terjadi, seperti banjir dan banjir pasang (rob). Banjir dan rob merupakan peristiwa menggenangnya air di daratan secara luas, khususnya untuk banjir pasang. Menurut Marfai (2003), rob merupakan bencana banjir berupa masuknya air laut ke darat akibat dari peristiwa pasang surut air laut.

Kawasan pesisir merupakan kawasan peralihan antara ekosistem laut dan darat (Kay \& Alder, 2005). Pada sebagaian besar kawasan pesisir, bencana menjadi ancaman terbesar terhadap keberlangsungan aktivitas sosio-ekonomi masyarakat pesisir (Fakhruddin \& Rahman, 2015). Mileti dan Peek-Gottschlich (2001) mengungkapkan bahwa terdapat tiga sistem utama yang akan mengalami dampak bencana, yaitu lingkungan fisik, sosial kependudukan, dan lingkungan terbangun. Kondisi sosial kependudukan menunjukkan karakter masyarakat pedesaan di pesisir yang relatif rentan terhadap paparan bencana.

Masyarakat pedesaan di pesisir rentan terhadap paparan bencana karena ketergantungannya terhadap sumberdaya pesisir (Shah, Dulal, Johnson, \& Baptiste, 2013). Umumnya, masyarakat pedesaan di pesisir bekerja pada sektor kepesisiran sebagai nelayan yang sangat bergantung pada sumber daya alam (Forster, Lake, Watkinson, \& Gill, 2014). Pada kondisi ini, masyarakat pedesaan di pesisir secara langsung maupun tidak langsung akan bergantung pada keberlangsungan sumber daya alam pesisir (Osbahr, Twyman, Adger, \& Thomas, 2008). Hal inilah yang mengakibatkan masyarakat pedesaan di pesisir secara sosio-ekonomi menjadi rentan bahkan terkadang tidak mampu untuk beradaptasi.

Mengingat hubungan antara ketersediaan sumber daya pesisir dan sosio-ekonomi masyarakat pedesaan di pesisir, maka segala macam bentuk bencana alam yang dapat mengganggu sumber daya pesisir beperngaruh terhadap penghidupan masyarakat. Bencana alam di wilayah pedesaan pesisir tidak hanya berkaitan dengan fisik lokasi bencana, namun juga berkaitan dengan aktivitas di lokasi tersebut. Kaitan tersebut dapat berupa kaitan penyebab maupun dampak dari bencana. Bencana alam dapat terjadi karena aktivitas manusia, dan bencana alam dapat pula berdampak pada aktivitas manusia. Hal ini akan selalu menjadi sebuah siklus apabila kesadaran peren masyarakat masih rendah. Untuk itu, penelitian ini dilakukan dalam rangka untuk menilai kerentanan sosial ekonomi masyarakat pedesaan di pesisir terhadap dampak bencana alam banjir dan rob. Penelitian 
ini diharapkan dapat membantu dalam memberikan masukan mengenai peningkatan peran serta masyarakat dalam menghadapi dan merespon bencana banjir dan banjir rob.

\section{Metode Penelitian}

\section{Wilayah Penelitian}

Penelitian ini difokuskan pada karakteristik sosio-ekonomi masyarakat serta kerentanannya terhadap kebencanaan banjir dan rob di wilayah pedesaan di pesisir Kabupaten Demak yang terdiri dari 4 (empat) wilayah kecamatan, yaitu Kecamatan Sayung, Karang Tengah, Bonang, dan Wedung (Gambar 1). Kabupaten Demak terletak di bagian Utara Pulau Jawa dengan kondisi topografi yang cukup datar serta sebagian wilayahnya berada di pesisir. Berdasarkan peta kebencanaan Provinsi Jawa Tengah, sebagian besar wilayah Kabupaten Demak merupakan wilayah dengan resiko banjir serta hampir seluruh wilayah utara Kabupaten Demak berisiko terkena rob sedangkan kondisi permukimannya padat. Dengan demikian, kerentanan sosial ekonomi di pedesaan pesisir menjadi lebih terancam.

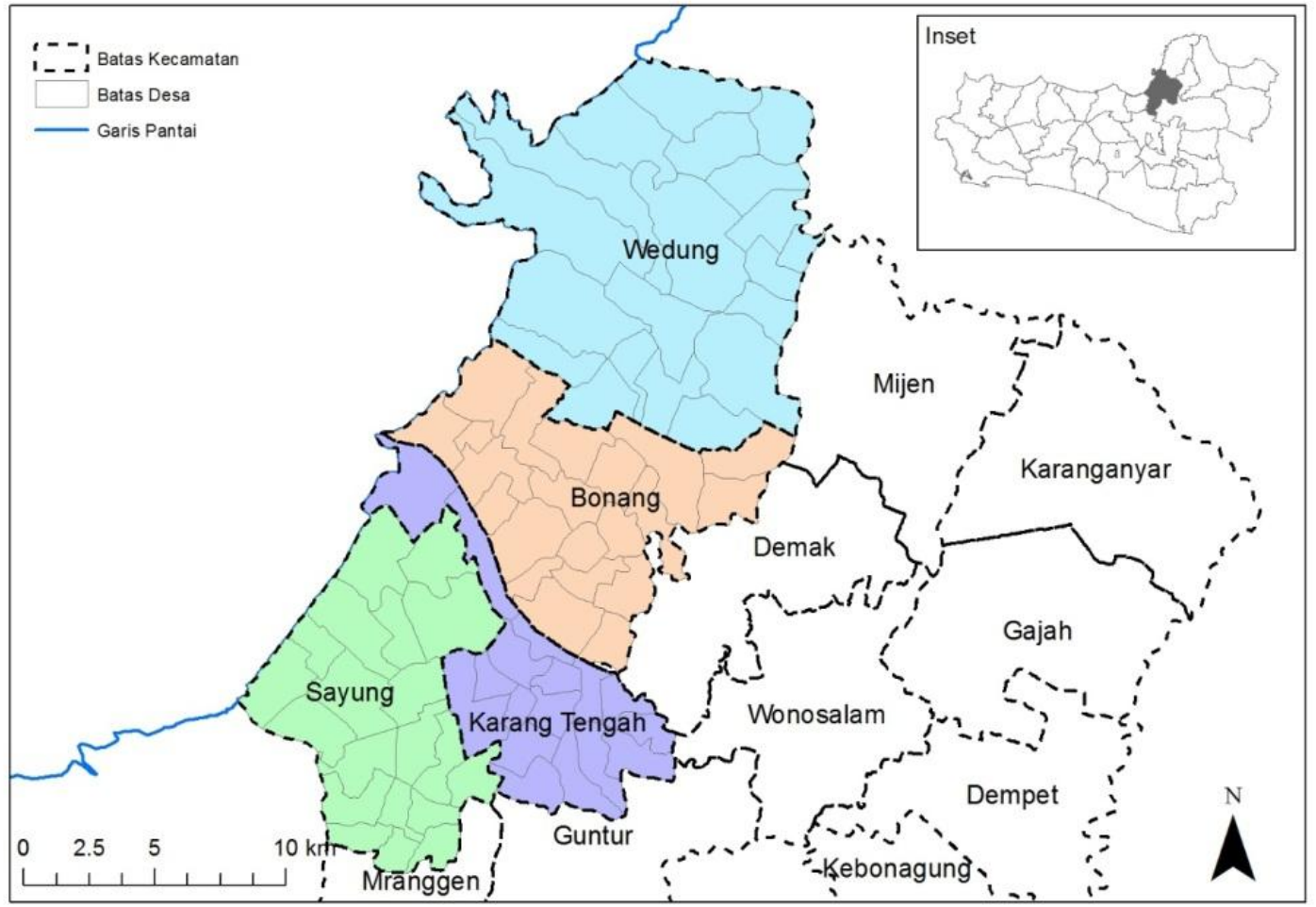

Sumber: Penyusun, 2016

Gambar 1. Peta Wilayah Penelitian 


\section{Kerentanan Sosio-Ekonomi terhadap Paparan Banjir dan Rob di Pedesaan Pesisir Kabupaten Demak}

\section{Teknik Analisis}

Studi ini menggunakan 2 langkah analisis. Tahap pertama adalah analisis overlay peta sebagai upaya memperlihatkan kondisi kerentanan sosio-ekonomi masyarakat secara spasial. Tahap kedua adalah penilaian kerentanan sosio-ekonomi. Lebih jelas mengenai teknik analisis yang digunakan dijabarkan sebagai berikut:

1) Analisis OverlayPeta

Dalam sistem informasi geografis dikenal teknik overlay, yaitu teknik overlay logika dan teknik overlay aritmatika. Overlay logika adalah metode untuk mendapatkan peta melalui klasifikasi irisan antara dua layer informasi. Ada 4 (empat) jenis yang termasuk overlay ini, yaitu: impose, stamp, joint dan matrix. Untuk mendapatkan peta yang didasarkan pada analisis komparatif dua layer peta. Metode ini didasarkan pada suatu matrix dimana layer peta 1 menyatakan baris dan layer peta 2 menyatakan kolom. Klasifikasi peta baru merupakan hasil perpotongan layer-layer peta ini berdasarkan matrix. Untuk mendapatkan peta baru berdasarkan operasi aritmatika (tambah, kurang dan pembagian) pada nilai atribut. Overlay ini digunakan bilamana pembobotan merupakan hal yang dipentingkan dalam analisisnya. Analisis overlay peta dipergunakan untuk mendapatkan temuan studi, yaitu kerentanan sosio-ekonomi masyarakat dengan mengoverlay-kan kondisi sosio-ekonomi masyarakat dengan paparan bencana banjir dan rob.

2) Penilaian kerentanan sosio-ekonomi masyarakat terhadap paparan bencana banjir dan rob

Penilaian kerentanan pada studi ini didasarkan pada tiga komponen kerentanan, yaitu sosial, ekonomi dan kebencanaan. Hal tersebut sesuai dengan tujuan penelitian untuk melihat kerentanan sosio-ekonomi masayarakat pedesaan di pesisir Kabupaten Demak terhadap paparan bencana seperti banjir dan rob. Pada penelitian ini, ketiga komponen keretanan dan indikatornya tersebut dianggap memiliki bobot yang sama karena didasarkan pada observasi lapangan tidak terdapat salah satu komponen yang memiliki pengaruh yang lebih besar dibanding komponen lainnya. Penilaian kerentanan ini mengadopsi metode penelitian kerentanan oleh Hahn, Riederer, dan Foster (2009). Tahapan penilaian ini terbagi ke dalam 4 (empat) tahap, yaitu:

1. Mengkonversikan data ke dalam unit data yang telah ditentukan pada Tabel 1;

2. Standarisasi nilai dengan mengadopsi rumus HDI (Human Development Index);

$$
\text { indeks standarisasi }=\frac{\text { nilai aktual }- \text { nilai } \min }{\text { nilai }}
$$

3. Mengambil rata-rata sembilan indikator sebagai nilai indeks kerentanan. Dimana indeks kerentanannya di antara nilai 0,24 hingga 0,52, yang berasal dari nilai terendah dan tertinggi rata-rata tersebut;

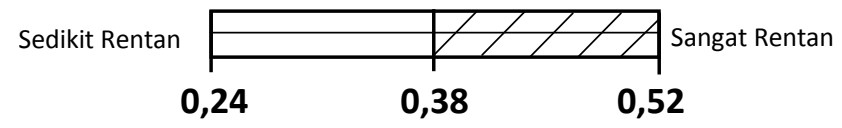


Tabel 1. Desain Penilaian Kerentanan Sosio-Ekonomi terhadap Bencana Banjir dan Rob

\begin{tabular}{|c|c|c|c|}
\hline $\begin{array}{l}\text { Komponen } \\
\text { Kerentanan }\end{array}$ & Indikator & Data & Unit \\
\hline \multirow{6}{*}{ Sosial } & Tingkat pendidikan & $\begin{array}{l}\text { Persentase penduduk usia } 10 \text { tahun ke } \\
\text { atas yang tidak tamat sekolah dasar }\end{array}$ & Persen \\
\hline & $\begin{array}{l}\text { Rasio } \\
\text { Keteroantunnoan }\end{array}$ & Rasio ketergantungan & Rasio \\
\hline & $\begin{array}{l}\text { Jumlah anggota } \\
\text { keluarga dalam } 1 \mathrm{KK}\end{array}$ & $\begin{array}{l}\text { Rata-rata jumlah anggota rumah } \\
\text { tangga }\end{array}$ & Satuan jiwa \\
\hline & $\begin{array}{l}\text { Pertumbuhan } \\
\text { Penduduk }\end{array}$ & Pertumbuhan penduduk & Persen \\
\hline & Kepadatan Penduduk & Kepadatan penduduk & Jiwa $/ \mathrm{km}^{2}$ \\
\hline & Jaminan Kesehatan & $\begin{array}{l}\text { Persentase penduduk penerima } \\
\text { JAMKESMAS }\end{array}$ & Persen \\
\hline \multirow{2}{*}{ Ekonomi } & Mata Pencaharian & $\begin{array}{l}\text { Persentase penduduk usia } 10 \text { tahun ke } \\
\text { atas yang bekerja di sektor primer }\end{array}$ & Persen \\
\hline & Pendapatan & $\begin{array}{l}\text { Persentase penduduk penerima surat } \\
\text { miskin }\end{array}$ & Persen \\
\hline Kebencanaan & $\begin{array}{l}\text { Kejadian bencana } \\
\text { banjir dan rob }\end{array}$ & Kejadian bencanan banjir dan rob & Satuan kejadian \\
\hline
\end{tabular}

\section{Hasil dan Pembahasan}

\section{Kejadian Bencana Banjir dan Rob Pesisir Demak}

Kawasan pesisir Kabupaten Demak telah terpapar oleh bencana banjir serta banjir pasang (rob). Akan tetapi, secara spasial tidak semua desa di pesisir Demak terpapar oleh kedua-duanya melainkan terdapat desa dengan berbagai macam kategori, seperti; hanya terpapar banjir, terpapar rob, atau terpapar keduannya, bahkan tidak terpapar oleh keduanya. Seperti terlihat pada Gambar 2., kejadian bencana banjir dan rob pada Kecamatan Sayung, Karang Tengah, Bonang, dan Kecamatan Wedung tersebar dan terkategori pada:

1. Banjir saja : Desa Prampelan, Pilangsari, Sidorejo, dan Desa Tambakroto (Kecamatan Sayung), Desa Dukun, Grogol, Ploso, Tambakbulusan, Wonoagung, dan Desa Wonokerto (Kecamatan Karang Tengah), serta Desa Karangrejo dan Desa Purworejo (Kecamatan Bonang).

2. Rob saja : Desa Bedono, Loireng, Sidogemah, Sriwulan, dan Desa Timbulsloko (Kecamatan Sayung), Desa Rejosari (Kecamatan Karang Tengah), serta Desa Betahwalang (Kecamatan Bonang).

3. Banjir dan Rob : Desa Surodadi dan Desa Tugu (Kecamatan Sayung). 


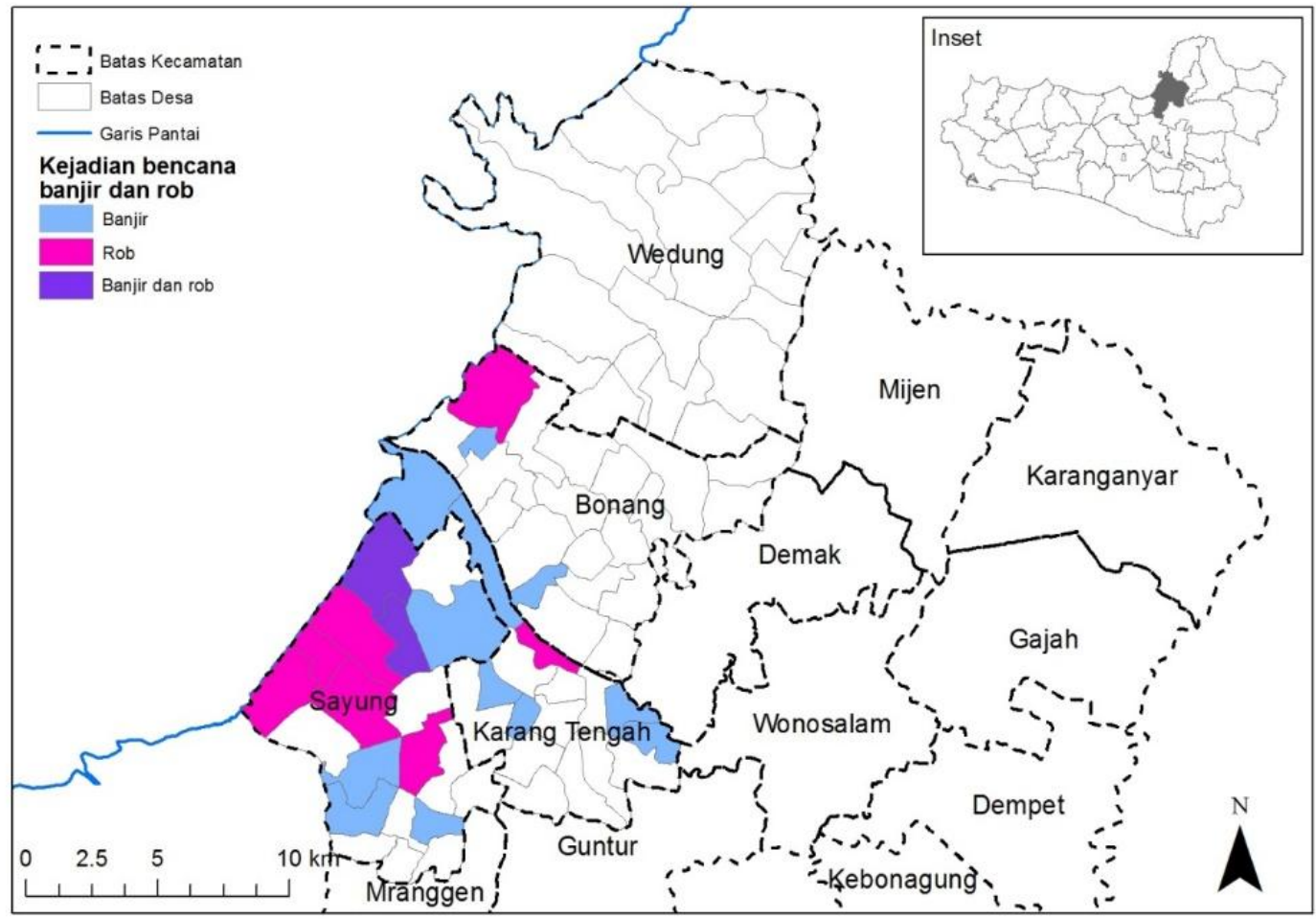

Sumber: Penyusun, 2016

Gambar 2. Peta Sebaran Kejadian Bencana Banjir dan Rob

\section{Kondisi Sosio-Ekonomi Masyarakat Pesisir Demak}

\section{Tingkat Pendidikan}

Data yang digunakan untuk variabel tingkat pendidikan adalah menggunakan persentase penduduk yang tidak tamat pendidikan dasar (SD). Dengan asumsi bahwa penduduk yang tidak tamat SD akan lebih rentan terhadap bencana. Sehingga semakin tinggi persentase penduduk tidak tamat SD pada suatu desa, maka desa tersebut akan semakin rentan terhadap bencana, karena dianggap pengetahuan masyarakatnya terhadap bencana masih kurang. Dari grafik di Gambar 3 dapat dilihat dari 4 kecamatan hanya sebagian kecil (dua desa) yang masyarakatnya lebih $48 \%$ tidak tamat SD.

Secara spasial dapat dilihat bahwa hanya sebagian kecil desa yang masyarakatnya tidak tamat SD. Pada Kecamatan Bonang terlihat bahwa secara keseluruhan masuk dalam klasifikasi paling rendah yaitu kurang dari $24 \%$ masyarakatnya yang tidak tamat SD (Gambar 4). Ini menunjukkan bahwa di Kecamatan Bonang masyarakatnya akan lebih tanggap terhadap bencana. 


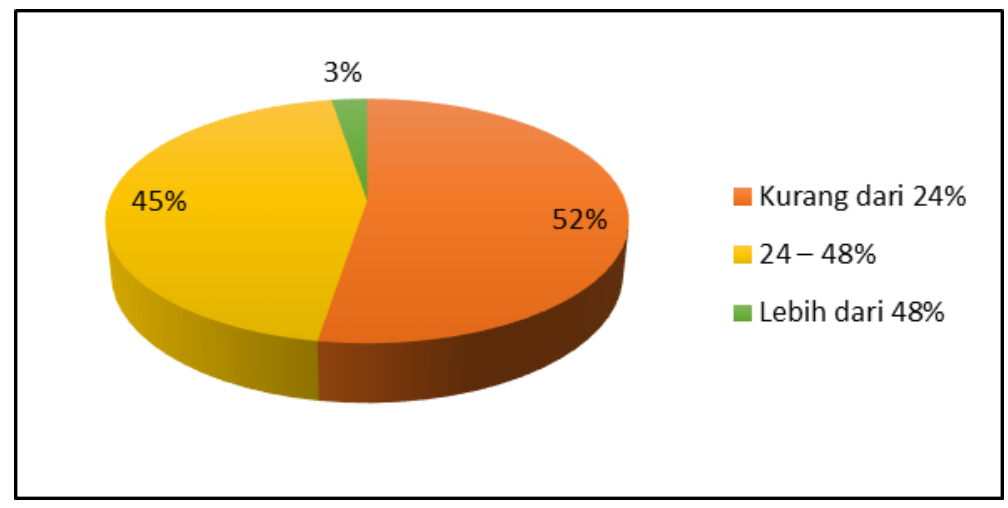

Sumber: Penyusun, 2016

Gambar 3. Persentase Desa Menurut Penduduk Tidak Tamat Pendidikan Dasar

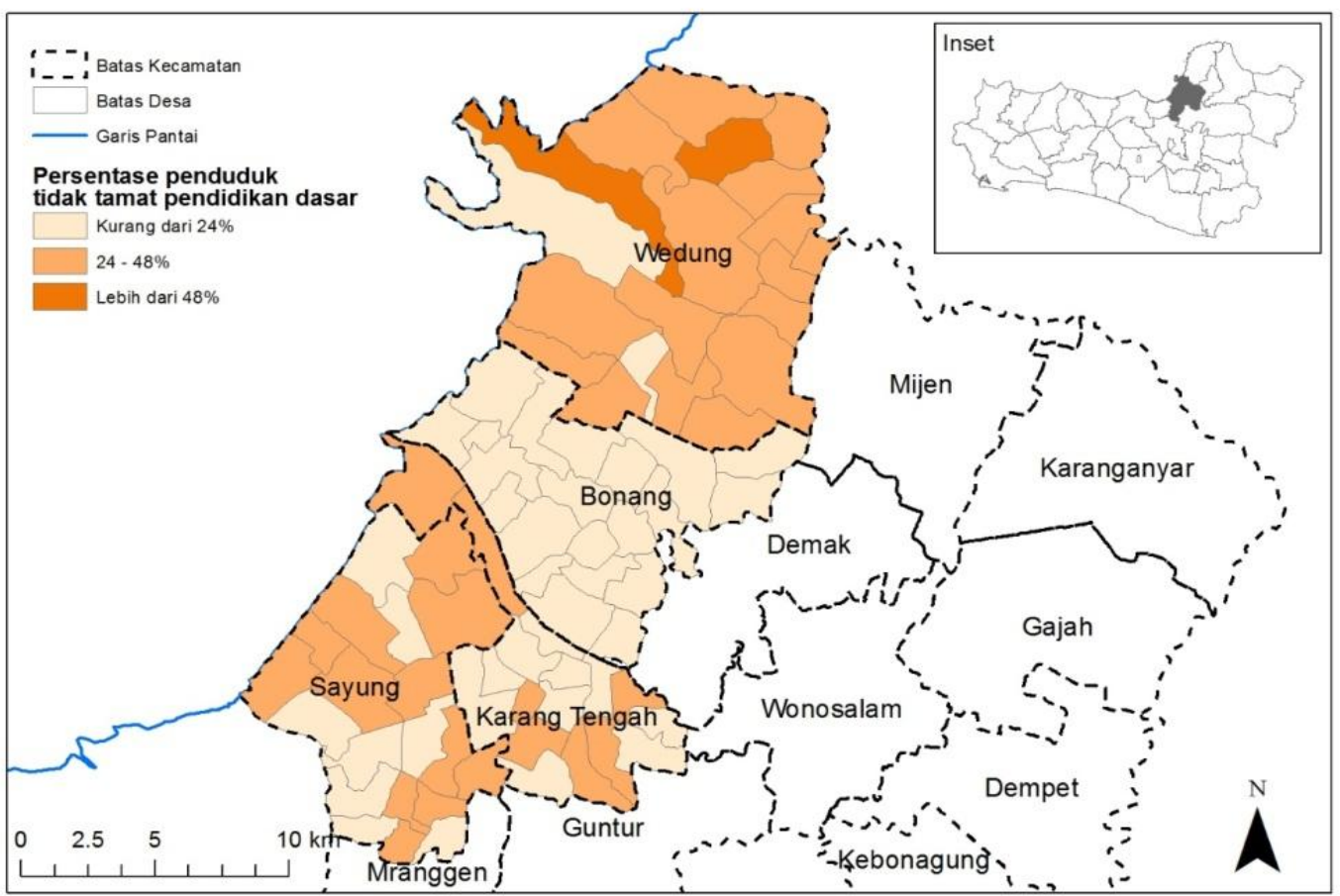

Sumber: Penyusun, 2016

Gambar 4. Peta Sebaran Persentase Penduduk Tidak Tamat Pendidikan Dasar

\section{$\underline{\text { Rasio Ketergantungan }}$}

Dari data rasio ketergantungan empat kecamatan yaitu Kecamatan Wedung, Bonang, Karang Tengah dan Sayung dapat dilihat persentase nilai tiap desa sebagimana tersajikan di grafik di Gambar 5. Asumsi yang digunakan adalah semakin tinggi persentase maka semakin tinggi tingkat kerentanan terhadap becana karena semakin tinggi pula beban yang harus ditanggung penduduk usia produktif untuk membiayai hidup penduduk yang belum dan tidak produktif. 


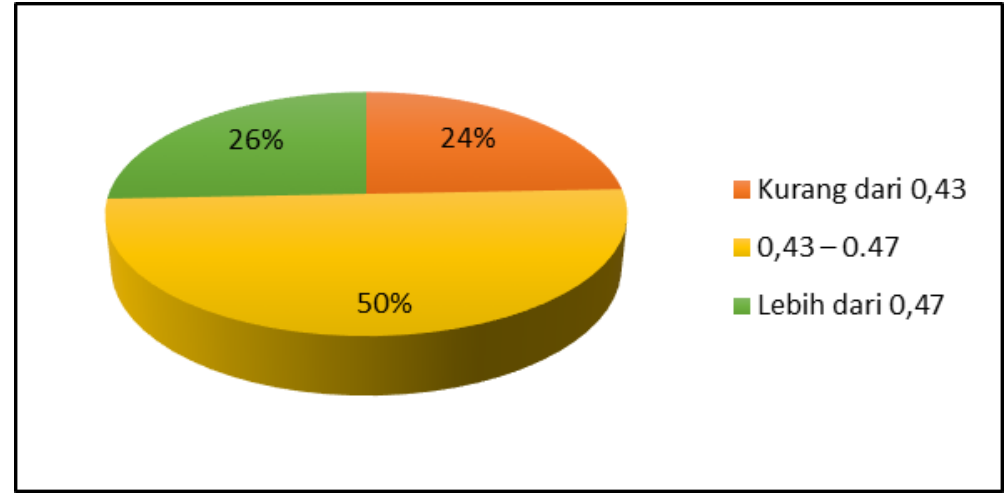

Sumber: Penyusun, 2016

\section{Gambar 5. Persentase Desa Menurut Rasio Ketergantungan}

Secara spasial dapat dilihat bahwa secara keseluruhan Kecamatan Karang Tengah memiliki persantase rasio ketergantungan yang tinggi, yaitu lebih dari $74 \%$. Sedangkan Kecamatan Sayung secara keseluruhan memiliki rasio ketergantungan yang rendah, yaitu 43\% (Gambar 6). Hal tersebut menandakan bahwa secara keseluruhan penduduk yang berada pada Kecamatan Sayung merupakan penduduk usia produktif sehingga terkategori paling tanggap terhadap bencana.

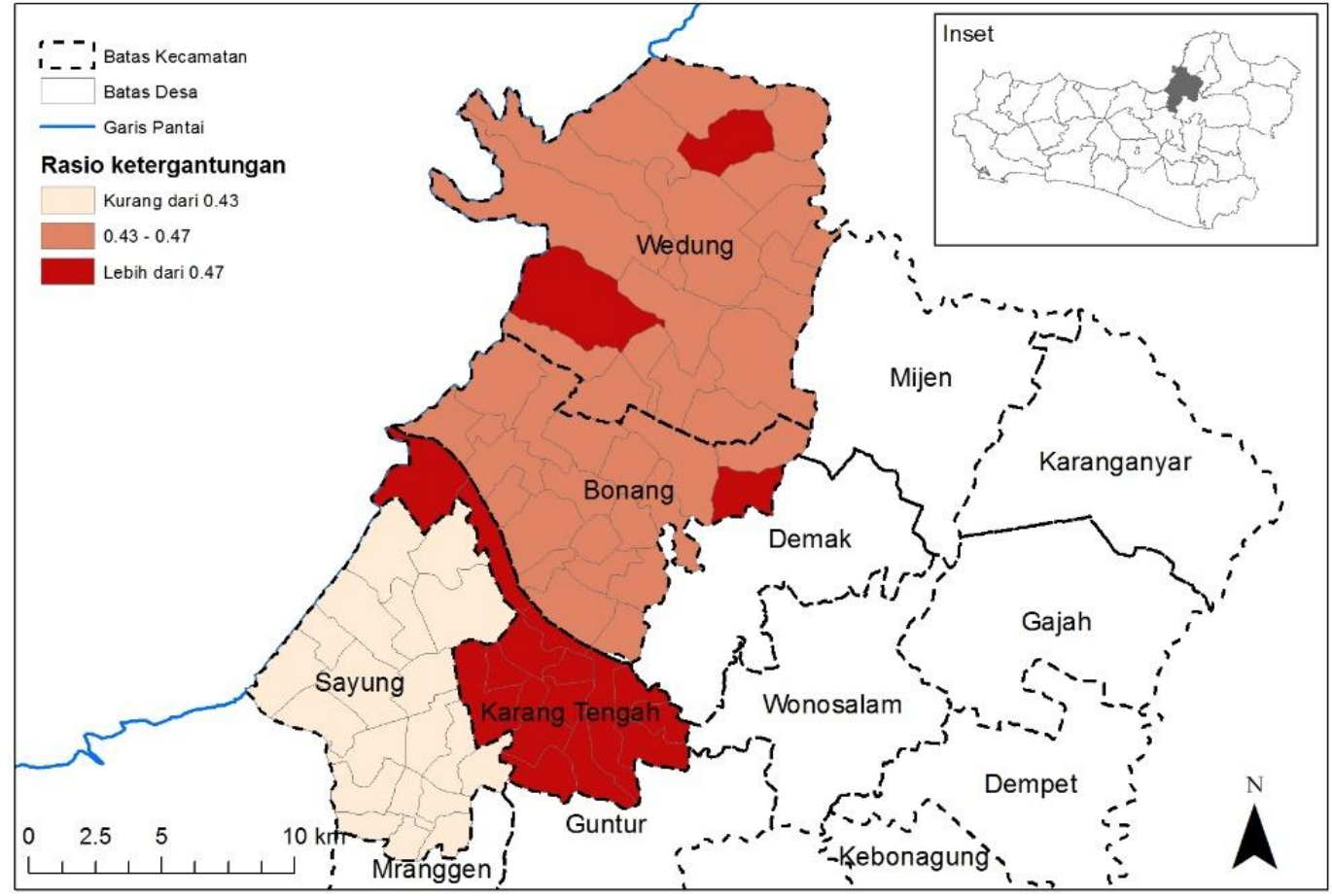

Sumber: Penyusun, 2016

Gambar 6. Peta Sebaran Rasio Ketergantungan 


\section{Rata-Rata Jumlah Anggota Rumah Tangga}

Dari data rata-rata jumlah anggota rumah tangga dengan satuan unit perdesa diketahui rata-rata jumlah anggota keluarga. Data dari empat kecamatan kemudian dijadikan tiga klasifikasi yaitu kurang dari 4 orang, 4-5 orang, dan lebih dari 5 orang. Setelah diklasifikasi, dapat dilihat bahwa mayoritas dari keseluruhan desa memiliki jumlah anggota keluarga kurang dari empat orang (Gambar 7). Dengan asumsi bahwa keluarga yang memiliki jumlah anggota sedikit akan lebih tanggap terhadap bencana, maka dapat disimpulkan bahwa berdasarkan rata-rata jumlah anggota rumah tangga, sebagian besar tanggap atau tidak rentan terhadap bencana.

Data yang ada kemudian dipetakan sehingga dapat dilihat persebarannya secara spasial (Gambar 8). Secara spasial dapat dilihat bahwa pada bagian utara atau di Kecamatan Wedung memiliki rata-rata jumlah anggota rumah tangga kurang dari empat orang, yang berarti kecamatan yang paling tanggap dari bencana berdasarkan data ratarata jumlah anggota dalam rumah tangga.

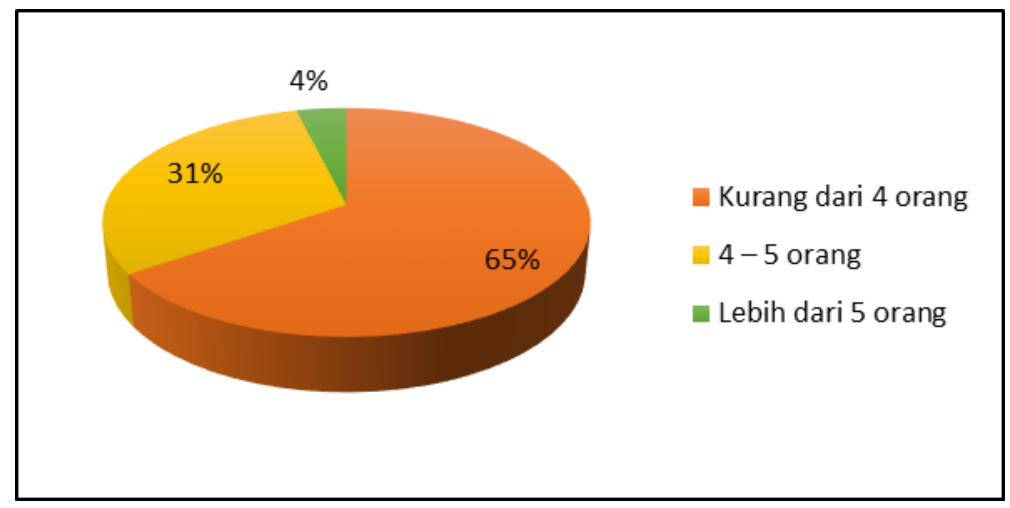

Sumber: Penyusun, 2016

\section{Gambar 7. Persentase Desa Menurut Rata-rata Jumlah Anggota Rumah Tangga}

\section{Pertumbuhan Penduduk}

Data pertumbuhan penduduk dari semua desa yang ada di 4 (empat) kecamatan di wilayah studi dibagi menjadi tiga klasifikasi berdasarkan persentase pertumbuhannya. Klasifikasi tersebut adalah menurun $-7 \%-0 \%$, meningkat $0 \%-1 \%$, dan meningkat lebih dari $1 \%$. Asumsi yang digunakan adalah jika pertumbuhan penduduk meningkat maka jumlah penduduk juga semakin bertambah, dan jika jumlah penduduknya banyak maka resiko objek yang terpapar akan semakin banyak, sehingga akan lebih rentan atau kurang tanggap terhadap bencana. Berdasarkan data pertumbuhan penduduk, diketahui bahwa terdapat 32 desa yang masuk dalam kategori menurun, 30 desa meningkat $0 \%-1 \%$ dan 16 desa yang meningkat lebih dari 1\% (Gambar 9).

Secara spasial dapat dilihat pertumbuhan penduduk yang meningkat berada pada bagian selatan dan tengah, dan pada bagian utara mayoritas mengalami penurunan pertumbuhan penduduk (Gambar 10). Hal tersebut menandakan bahwa pada bagian selatan dan tengah lebih rentan atau kurang tanggap terhadap bencana. 


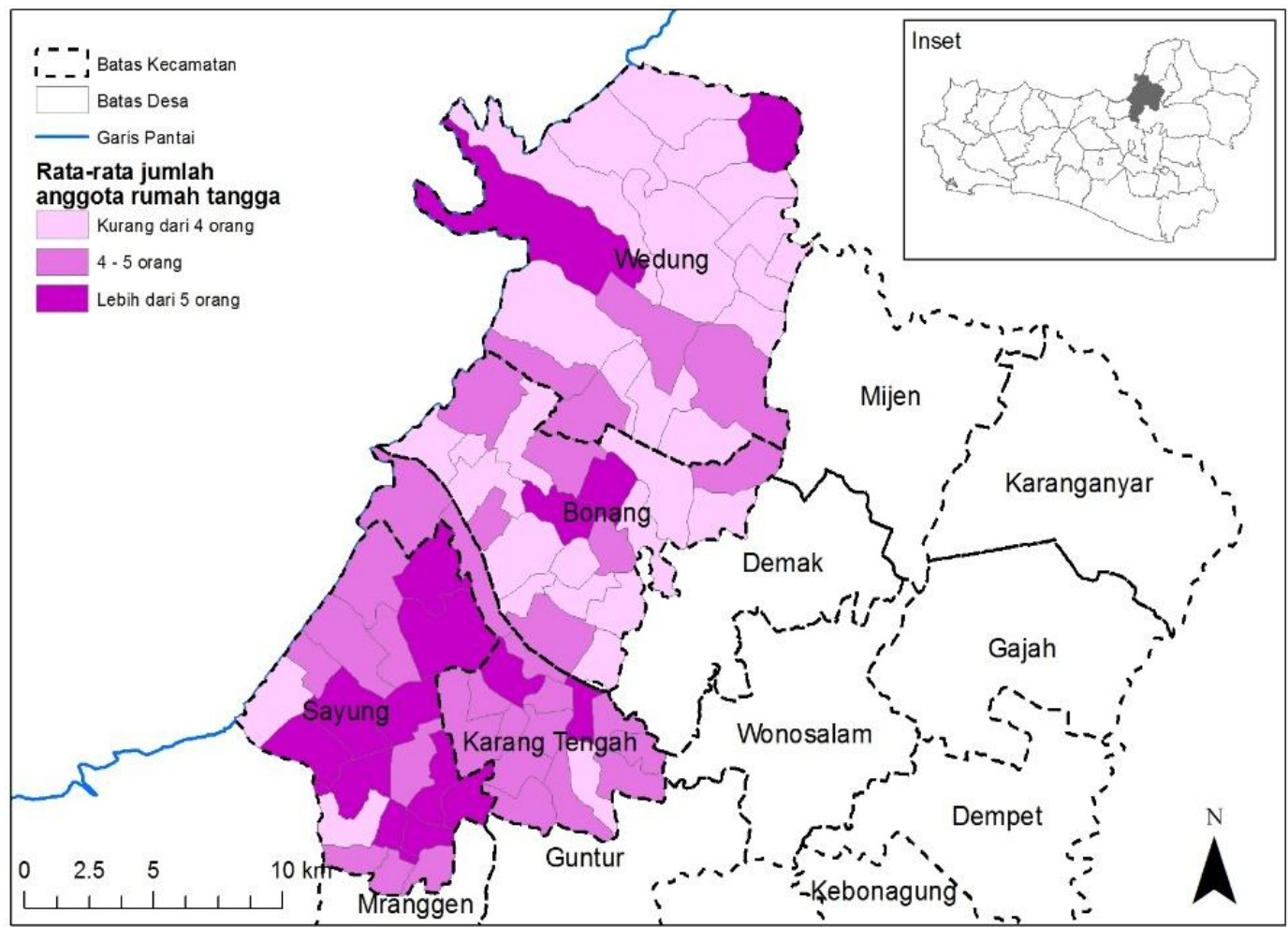

Sumber: Penyusun, 2016

Gambar 8. Peta Sebaran Rata-rata Jumlah Anggota Rumah Tangga

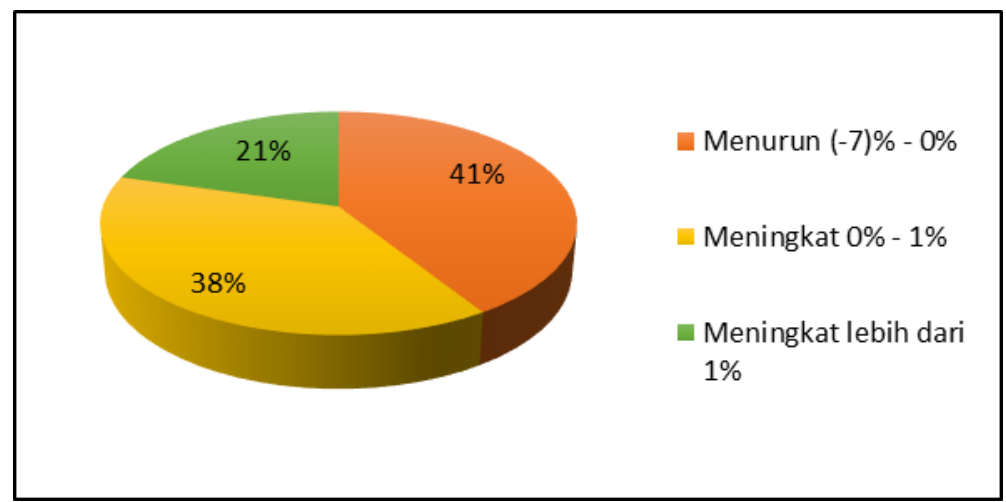

Sumber: Penyusun, 2016

Gambar 9. Persentase Desa Menurut Pertumbuhan Penduduk 


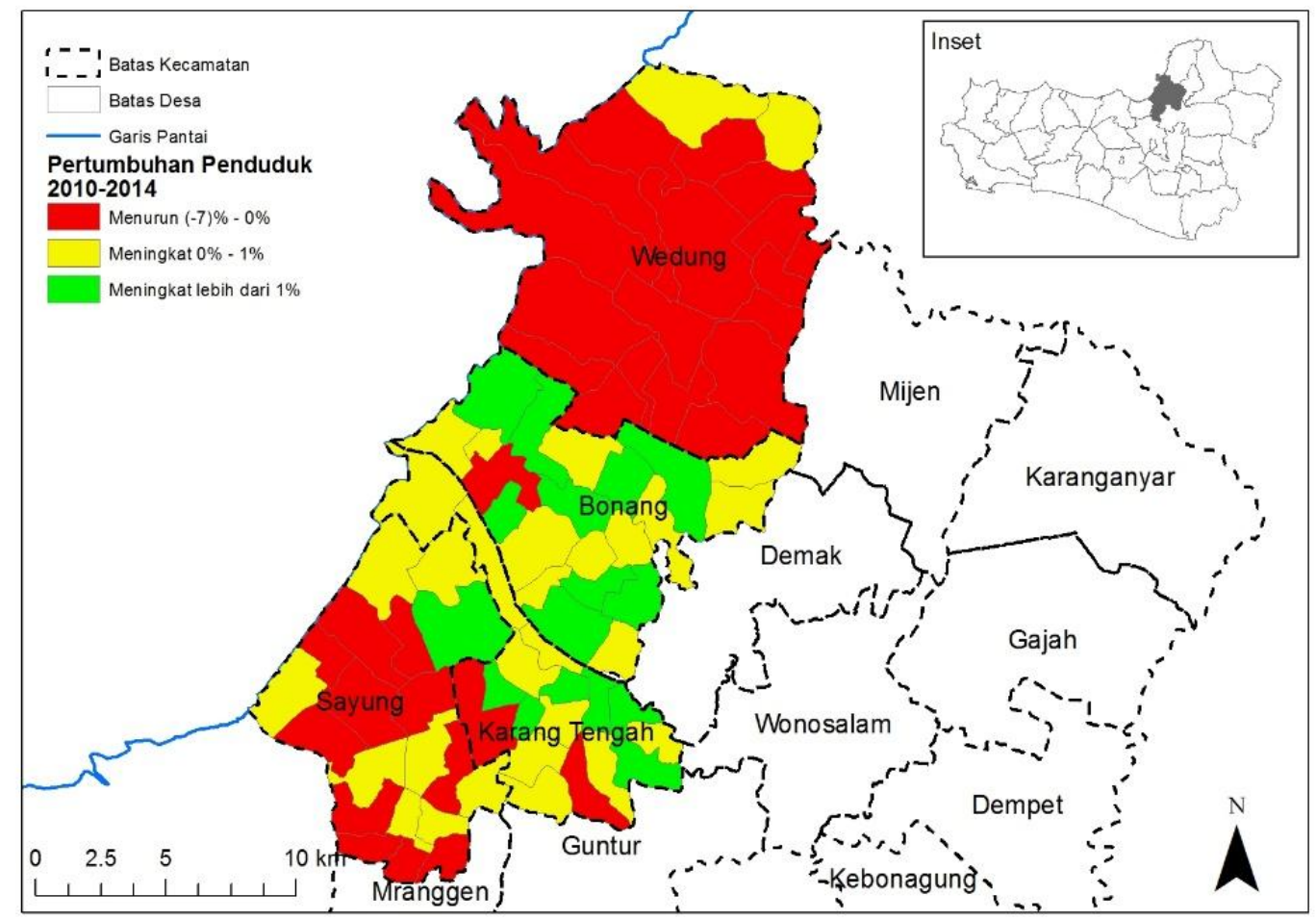

Sumber: Penyusun, 2016

\section{Gambar 10. Peta Sebaran Pertumbuhan Penduduk}

\section{Kepadatan Penduduk}

Berdsarkan data dari 4 (empat) kecamatan berupa jumlah penduduk dan luas wilayah, maka dapat diketahui tingkat kepadatan tiap desa. Dengan asumsi kepadatan penduduk berbanding lurus dengan tingkat kerentanan, maka semakin tinggi kepadatan penduduk maka semakin rentan daerah tersebut terhadap bencana (Gambar 11).

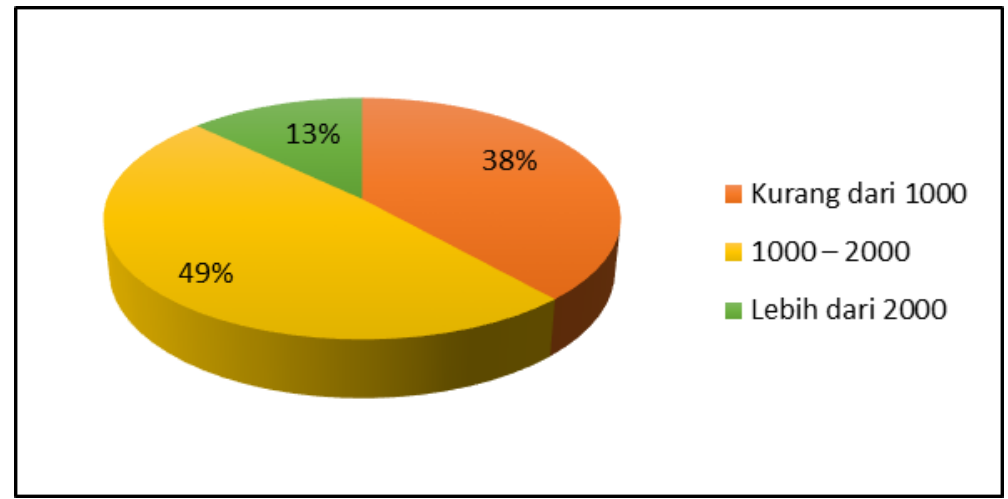

Sumber: Penyusun, 2016

Gambar 11. Persentase Desa Menurut Kepadatan Penduduk (jiwa/km²) 


\section{Kerentanan Sosio-Ekonomi terhadap Paparan Banjir dan Rob di Pedesaan Pesisir Kabupaten Demak}

Secara spasial dapat dilihat bahwa pada kepadatan penduduk yang tinggi hanya terjadi pada sebagian kecil di bagian selatan dan tengah, yaitu pada Kecamatan Sayung, Karangtengah dan Bonang. Hal tersebut dikarenakan ketiga kecamatan tersebut masih masuk dalam perkembangan metropolitan Semarang sehingga masih terdapat dampak dari urbaninsasi (Gambar 12).

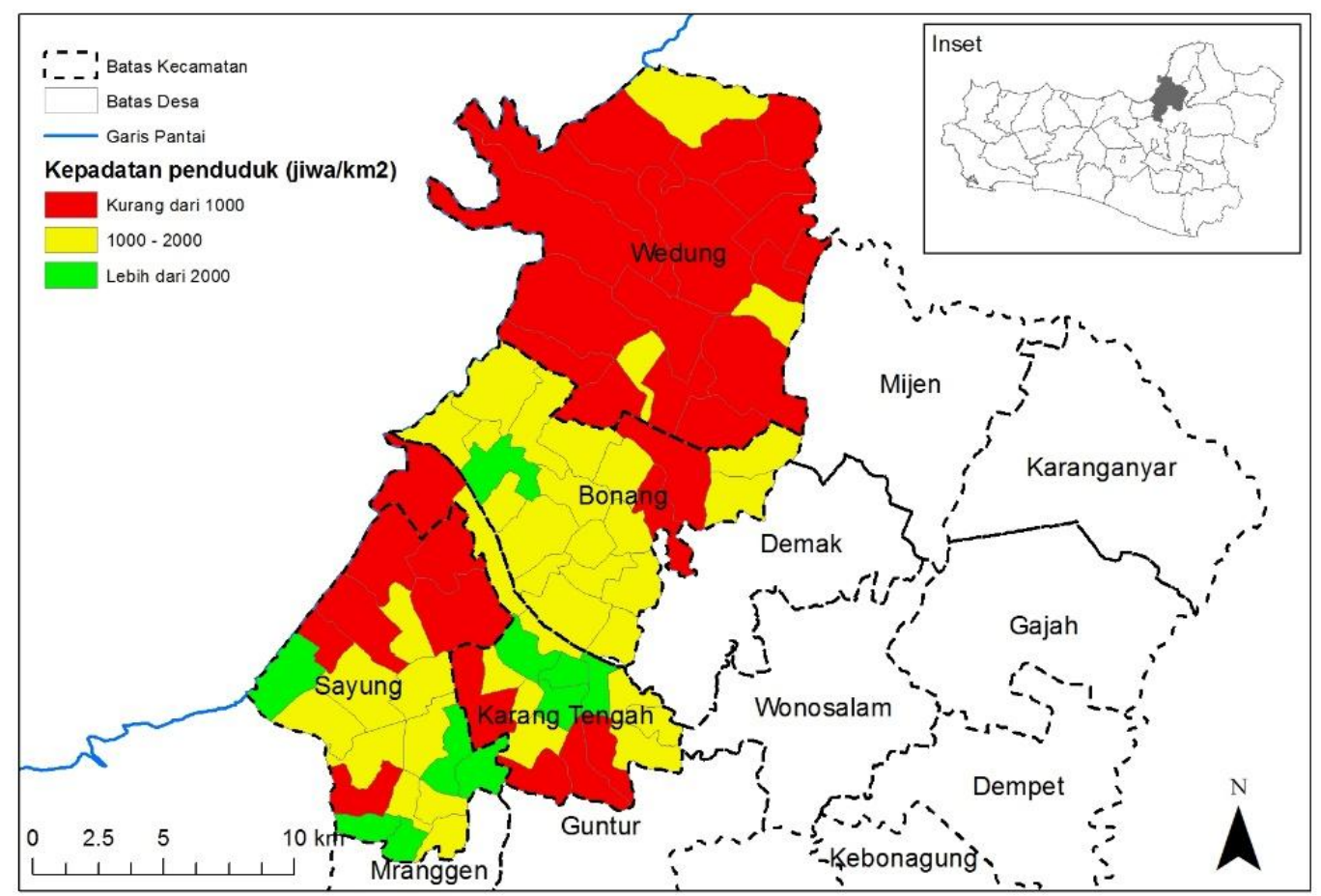

Sumber: Penyusun, 2016

Gambar 12. Peta Sebaran Kepadatan Penduduk

\section{Jaminan Kesehatan}

Berdasarkan data penerimaan jaminan kesehatan masyarakat (JAMKESMAS) yang kemudian di persentase dari jumlah penduduk tiap desa, dapat diketahui tingkat persebaran penerimaan layanan JAMKESMAS pada tiap desa. Data tersebut kemudian di bagi menjadi tiga klasifikasi dan dari perhitungan yang didapat hanya 11 desa yang masyarakatnya sudah menerima JAMKESMAS lebih dari 56\%. Sedangkan jumlah desa yang menerima JAMKESMAS kurang dari $28 \%$ sebanyak 23 desa dan sisanya atau sebanyak 44 desa telah menerima JAMKESMAS antara 28\% - 56\% (Gambar 13).

Kemudian data yang sudah diklasifikasikan tersebut dipetakan sehingga dapat dilihat persebarannya secara spasial. Dapat terlihat bahwa hanya sedikit desa yang lebih dari $56 \%$ penduduknya sudah menerima JAMKESMAS (Gambar 14). Dengan asusmsi masyarakat yang memiliki JAMKESMAS adalah masyarakat yang lebih tanggap terhadap bencana, maka berdasarkan persentase penduduk penerima JAMKESMAS sebagian besar masih rentan terhadap bencana. 


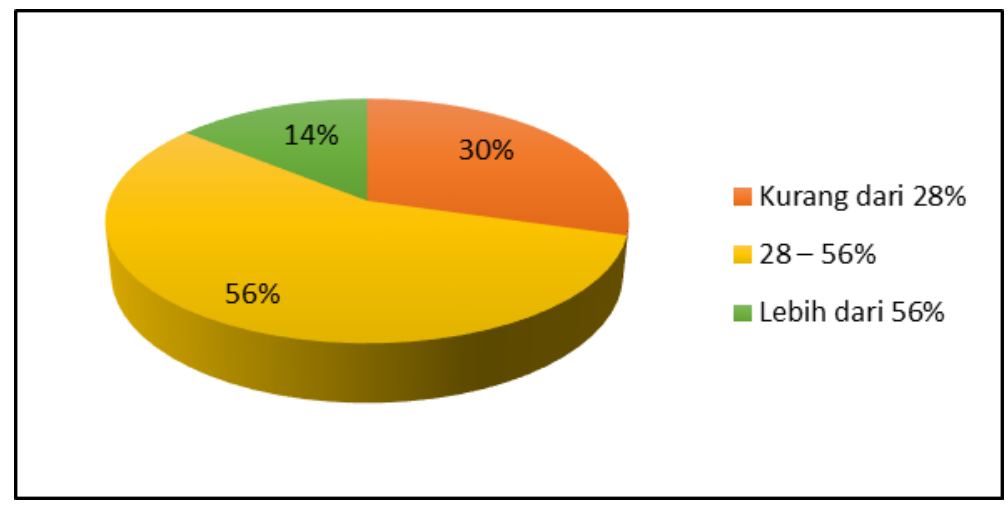

Sumber: Penyusun, 2016

Gambar 13. Persentase Desa Menurut Penduduk Penerima JAMKESMAS

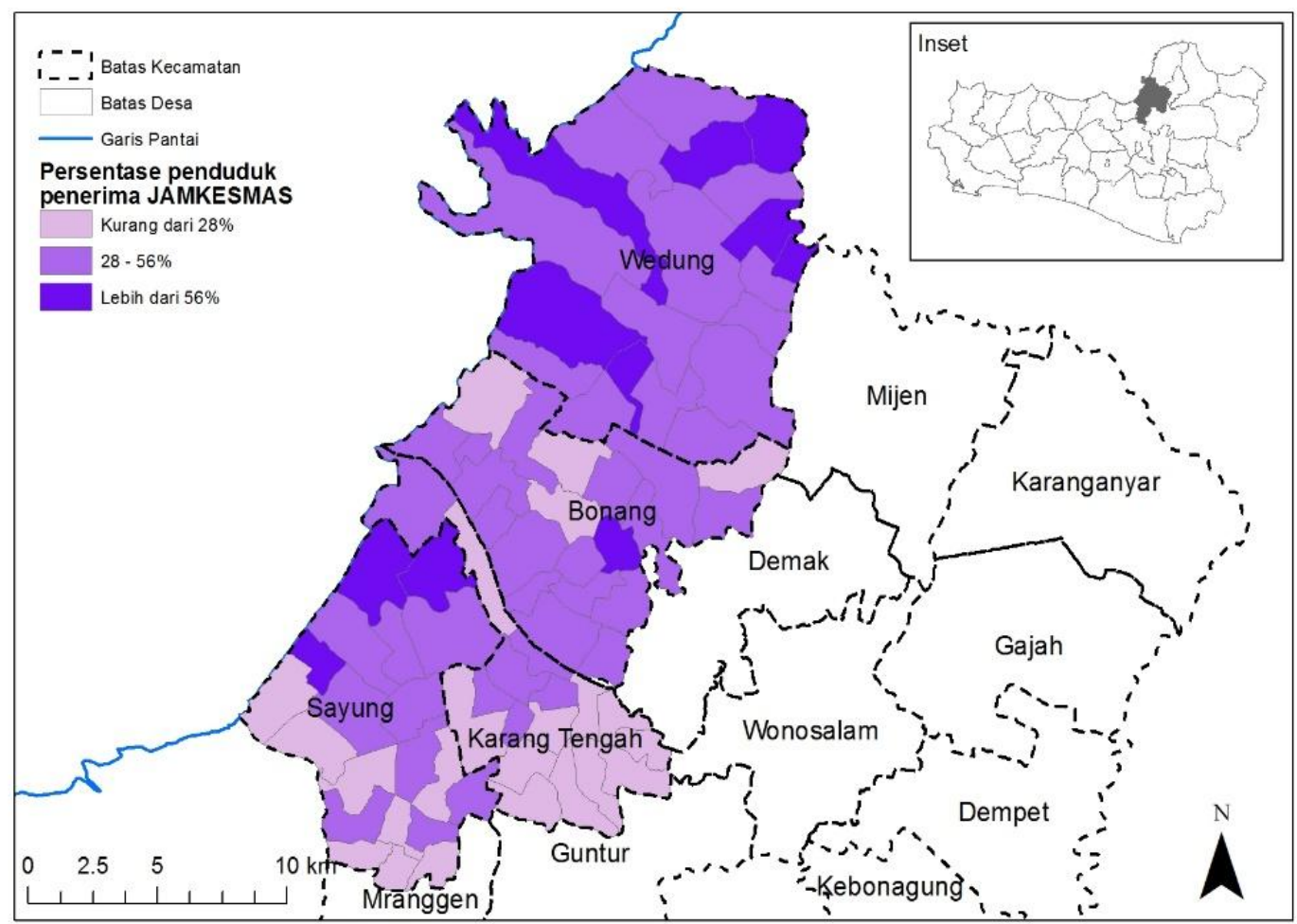

Sumber: Penyusun, 2016

\section{Gambar 14. Peta Sebaran Penduduk Penerima JAMKESMAS}

\section{Mata Pencaharian}

Persentase penduduk yang bekerja dibagi ke dalam 3 (tiga) klasifikasi yaitu kurang dari $24 \%$, 24\% - 48\%, serta lebih dari 48\%. Persentase ini merupakan jumlah penduduk yang bekerja di sektor primer seperti petani dan nelayan dibandingkan dengan jumlah penduduk yang berusia produktif di masing-masing desa. Dari hasil perbandingan didapatkan hasil sebagai berikut dan tergambarkan di Gambar 15. 
1. Sekitar $45 \%$ atau 35 desa merupakan desa dengan persentase penduduk yang bekerja di sektor primer yaitu kurang dari $24 \%$ jumlah usia produktif di setiap desa.

2. Sekitar $45 \%$ atau 35 desa merupakan desa dengan persentase penduduk yang bekerja di sektor primer berkisar antara $24 \%$ - $48 \%$ jumlah usia produktif di setiap desa.

3. Sekitar $10 \%$ atau 8 desa merupakan desa dengan persentase penduduk yang bekerja di sektor primer yaitu lebih dari $48 \%$ dari jumlah usia produktif di setiap desa.

Sektor primer yang digunakan dalam variabel ini yaitu petani dan nelayan di mana siklus pekerjaan dan pendapatan mereka sangat tergantung pada kondisi alam. Berdasarkan hasil di atas, maka desa dengan penduduk yang sebagian besar berprofesi di sektor primer hanya sebagian kecil sehingga diduga hanya sebagian kecil desa-desa di wilayah studi yang rentan secara ekonomi.

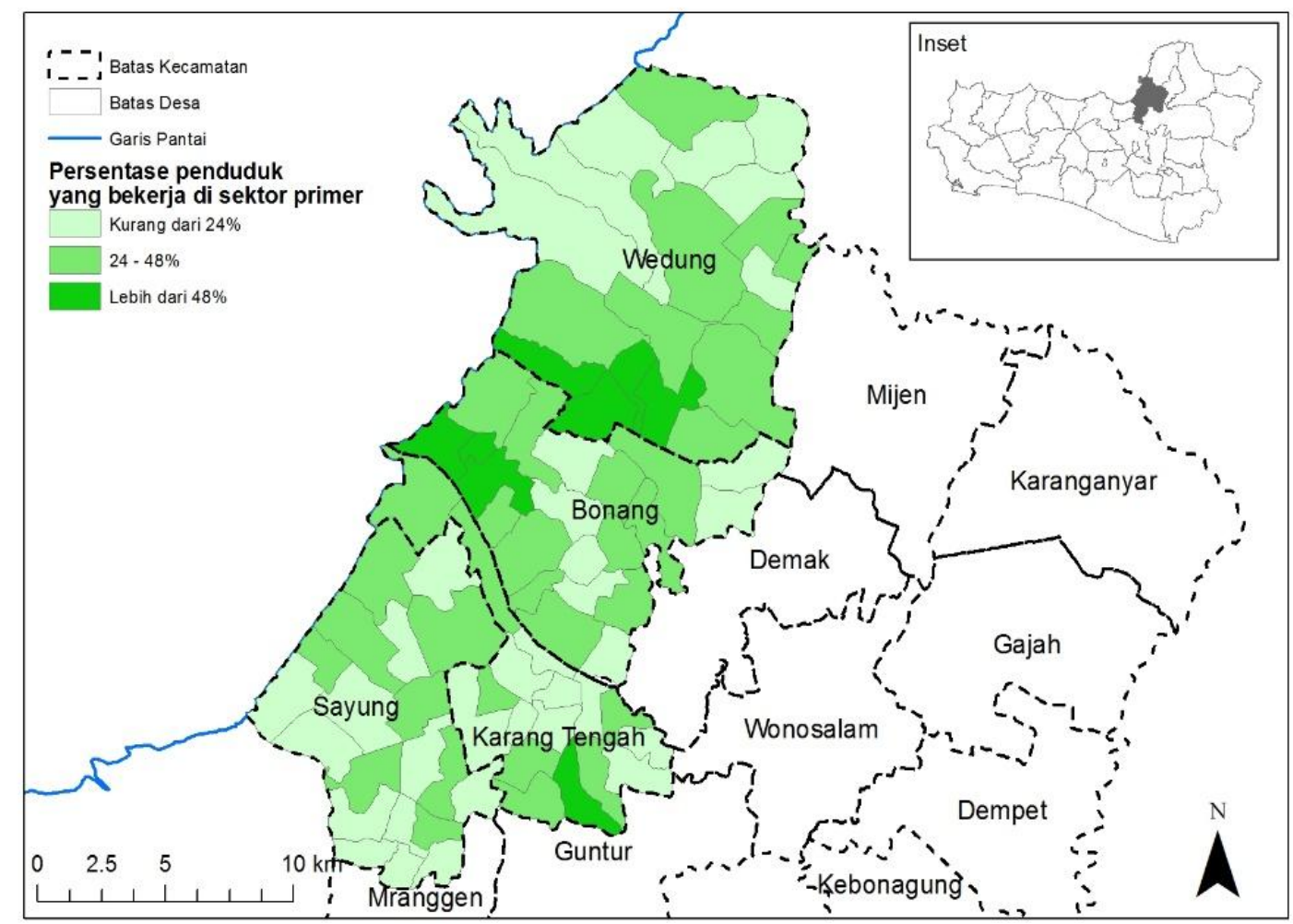

Sumber: Penyusun, 2016

Gambar 15. Peta Sebaran Persentase Penduduk yang Bekerja di Sektor Primer

\section{$\underline{\text { Pendapatan }}$}

Persentase penduduk penerima surat miskin dibagi menjadi 3 (tiga) klasifikasi, yaitu kurang dari $2 \%, 2 \%-6 \%$, dan lebih dari $6 \%$. Persentase ini merupakan perbandingan antara jumlah penduduk penerima surat miskin terhadap jumlah penduduk total di setiap desa dengan hasil sebagai berikut dan tergambarkan di peta pada Gambar 16.

1. Sekitar $58 \%$ dari total seluruh desa di wilayah studi atau 45 desa dengan persentase penduduk penerima surat miskin sebesar kurang dari $2 \%$ dari total jumlah penduduk di setiap desa. 
2. Sekitar $38 \%$ dari total seluruh desa di wilayah studi atau 30 desa dengan persentase penduduk penerima surat miskin sebesar $2 \%-6 \%$ dari total jumlah penduduk di setiap desa.

3. Sekitar $4 \%$ dari total seluruh desa di wilayah studi atau 3 desa dengan persentase penduduk penerima surat miskin sebesar lebih dari $6 \%$ dari total jumlah penduduk di setiap desa.

Hasil dari perbandingan yang dilakukan mengindikasikan bahwa sebagian besar desa di wilayah studi rata-rata penduduknya cukup sejahtera dan tangguh secara ekonomi.

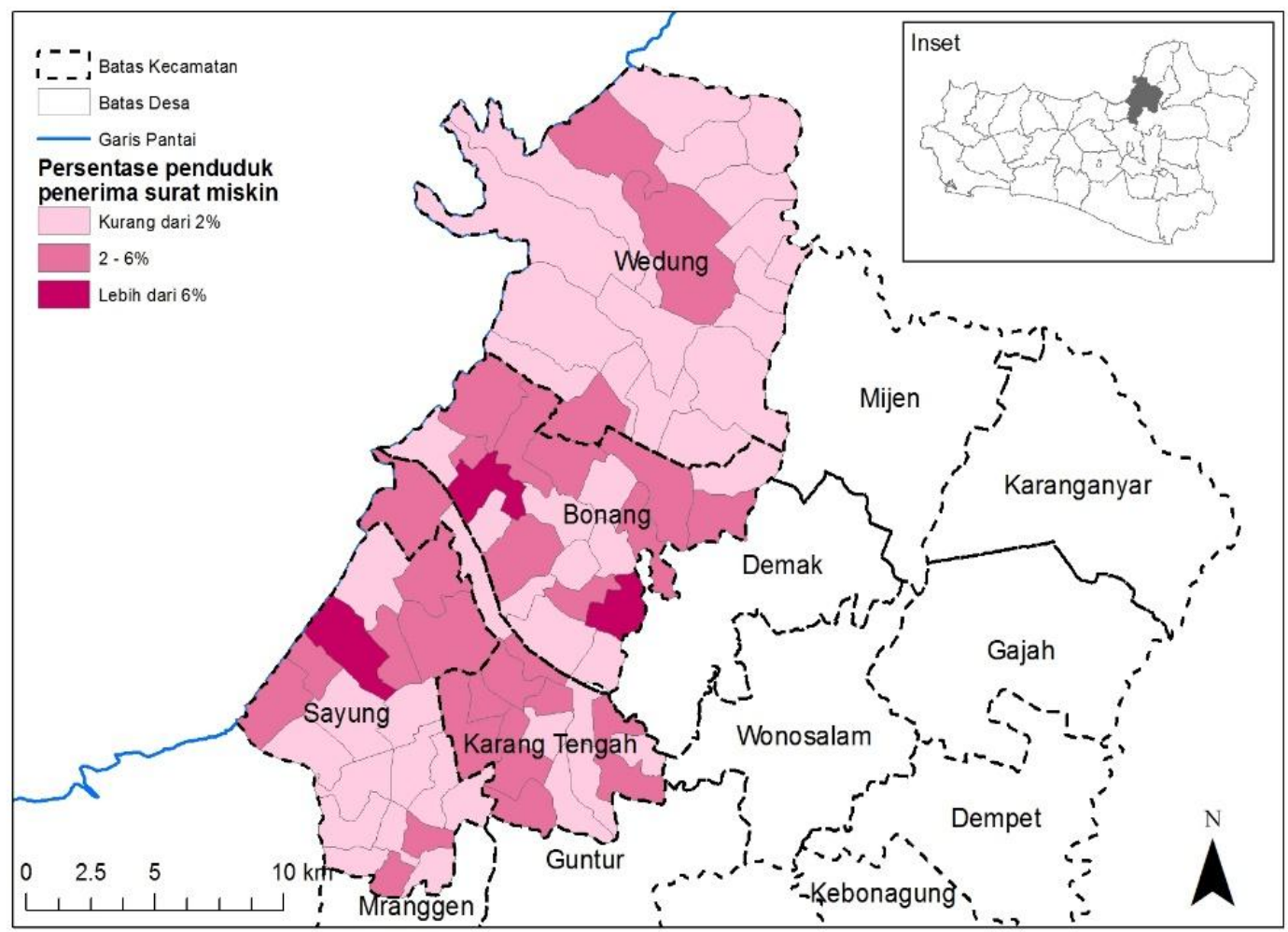

Sumber: Penyusun, 2016

Gambar 16. Peta Sebaran Persentase Penduduk Penerima Surat Miskin

\section{Kerentanan Sosio-Ekonomi Masyarakat terhadap Bencana Banjir dan Rob}

Setelah dilakukan analisis dan perhitungan dari semua variabel yang ada kemudian dikelompokkan menjadi dua bagian; yaitu kurang rentan (less vulnerable) dan paling rentan (most vulnerable). Pembagian tersebut dilakukan berdasarkan nilai minimum dan maksimum komponen sosial ekonomi, yang kemudian nilai tengah dijadikan sebagai batas pembagian nilai tersbut. Dari hasil perhitungan tersebut, maka dapat diketahui desa-desa yang ada di wilayah studi termasuk dalam kategori less vulnerable atau most vulnerable. Setelah dilakukan perhitungan dan pengklasifikasian dari hasil perhitungan, maka didapatkan 45 desa (58\%) yang termasuk dalam less vulnerable dan 33 desa (42\%) yang termasuk dalam kategori most vulnerable (Gambar 17). Hal ini menandakan bahwa sebagian besar desa masih termasuk dalam kategori tanggap terhadap bencana. 
Secara spasial, seperti yang ditunjukkan pada Gambar 18., sebagian besar desa yang berada di pesisir wilayah studi masuk dalam katagori most vulnerable. Hal ini menunjukkan bahwa bencana banjir dan rob pada wilayah yang terkategori most vulnerable tersebut akan semakin meningkatkan resiko penduduk yang tinggal di desa tersebut.

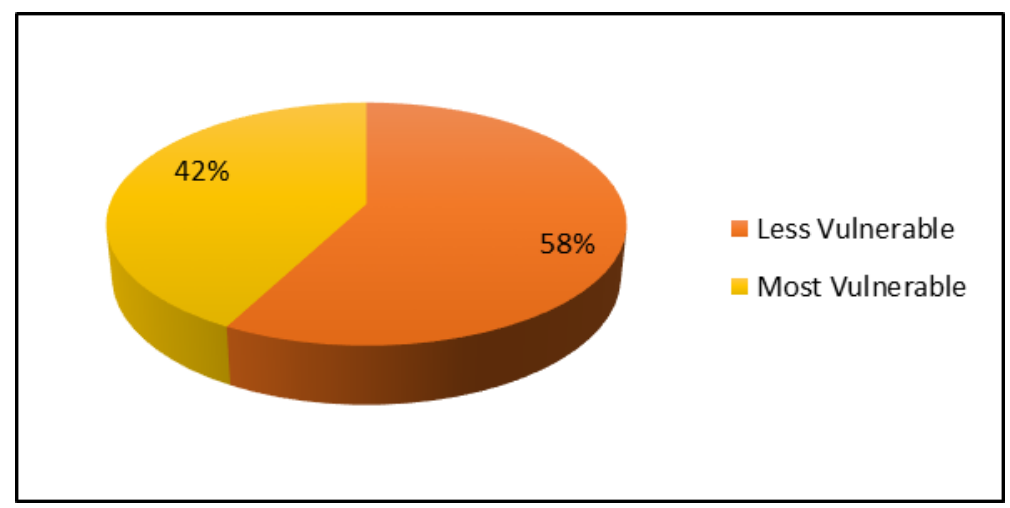

Sumber: Penyusun, 2016

\section{Gambar 17. Persentase Desa Menurut Tingkat Kerentanan Sosio-Ekonomi}

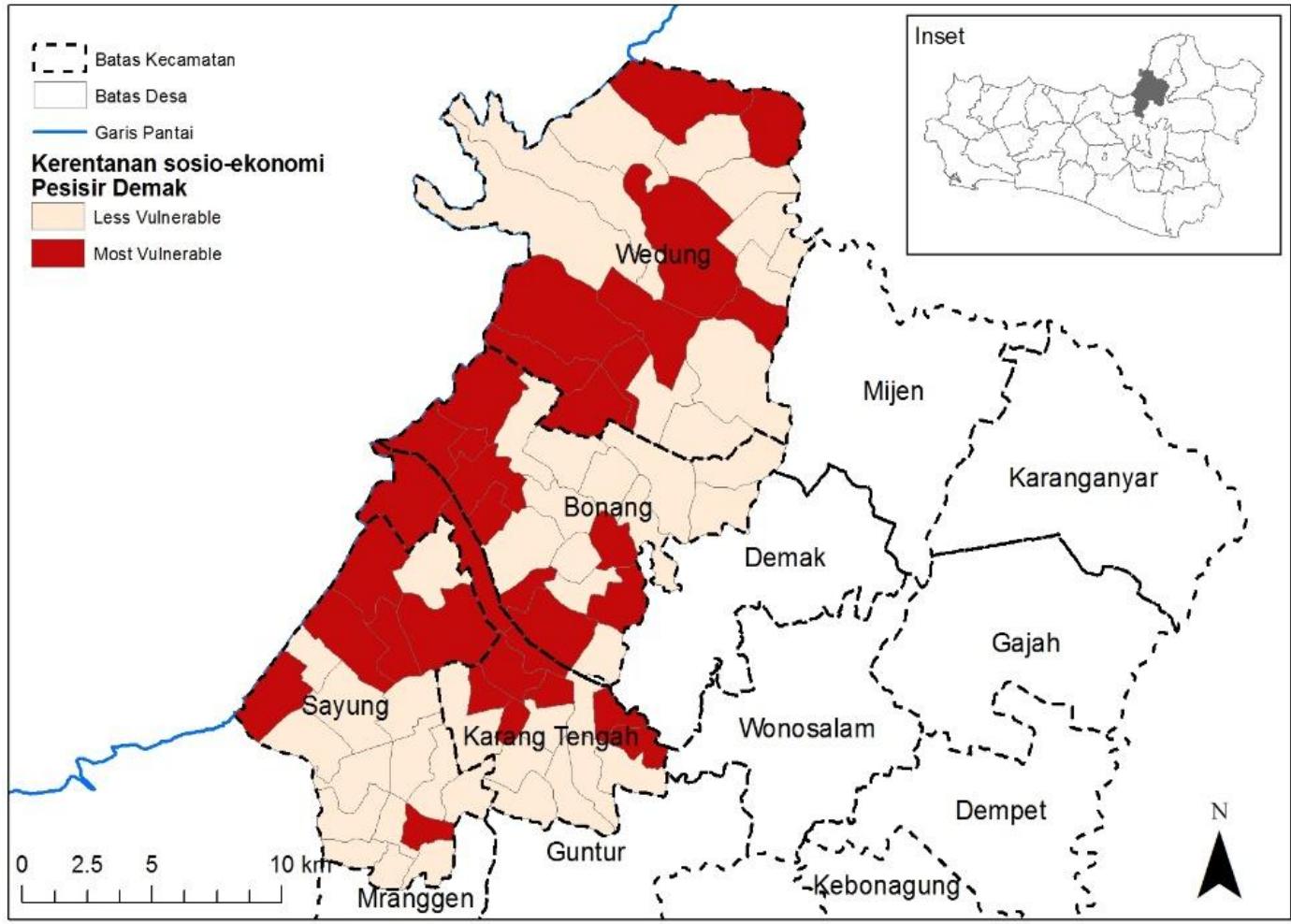

Sumber: Penyusun, 2016

\section{Gambar 18. Peta Sebaran Kerentanan Sosio-Ekonomi}




\section{Kesimpulan}

Sebagian besar desa yang terletak di pesisir memiliki tingkat kemiskinan tinggi disertai dengan tingginya jumlah penduduk yang bekerja di sektor primer sebagai petani dan nelayan yang mana sangat bergantung terhadap kondisi alam. Secara sosio-ekonomi, tingkat kerentanan di Kabupaten Demak menunjukkan angka yang hampir berimbang antara yang terkategori less vulnerable dan most vulnerable. Sebagian besar desa yang berada di pesisir Kabupaten Demak yang terkategori sebagai most vulnerable secara sosioekonomi juga berada pada desa yang terdapat bencana banjir, rob, atau keduanya. Desa yang mendapatkan status most vulnerable dan juga memiliki kedua jenis bencana banjir dan rob ditemukan di Kecamatan Sayung atau tepatnya di 2 (dua) desa. Sedangkan untuk desa-desa lain hanya terdapat bencana banjir atau rob saja. Hal ini menujukkan bahwa di desa yang terdapat kedua jenis bencana, yaitu banjir dan rob mempunyai tingkat resiko yang lebih tinggi sehingga diperlukan penanganan yang lebih terintegrasi. Walaupun demikian, desa-desa lain yang terkategori most vulnerable dengan salah satu jenis bencana, banjir atau rob saja, juga memerlukan penanganan lebih jauh agar masyarakat memiliki kemampuan tanggap bencana yang lebih baik. Hal yang paling penting adalah kesadaran dari masyarakat mengenai lokasi tempat tinggal yang tergolong rentan atau kurang rentan sehingga perlu ada upaya tanggap bencana. Hal ini diperlukan untuk mengurangi resiko keterpaparan akibat adanya bencana banjir dan rob.

\section{Daftar Pustaka}

Donohue, C., \& Biggs, E. (2015). Monitoring socio-environmental change for sustainable development: Developing a Multidimensional Livelihoods Index (MLI). Applied Geography, 62, 391-403. doi:10.1016/j.apgeog.2015.05.006.

Fakhruddin, S. H. M., \& Rahman, J. (2015). Coping with coastal risk and vulnerabilities in Bangladesh. International Journal of Disaster Risk Reduction, 12, 112-118. doi:10.1016/j.ijdrr.2014.12.008.

Fang, Y. P., Fan, J., Shen, M. Y., \& Song, M. Q. (2014). Sensitivity of livelihood strategy to livelihood capital in mountain areas: Empirical analysis based on different settlements in the upper reaches of the Minjiang River, China. Ecological Indicators, 38, 225-235. doi:10.1016/j.ecolind.2013.11.007.

Forster, J., Lake, I. R., Watkinson, A. R., \& Gill, J. A. (2014). Marine dependent livelihoods and resilience to environmental change: A case study of Anguilla. Marine Policy, 45, 204-212. doi:10.1016/j.marpol.2013.10.017.

Gitz, V., \& Meybeck, A. (2012). Risks, vulnerabilities and resilience in a context of climate change. In A. Meybeck, J., Lankoski, S. Redfern, N. Azuu, \& V. Gitz (Eds.), Building Resilience for Adaptation to Climate Change in the Agriculture Sector (pp. 19-36). Rome: Food and Agriculture Organization of the United Nations Organisaton for Economic Co-operation and Development.

Hahn, M. B., Riederer, A. M., \& Foster, S. O. (2009). The livelihood vulnerability index: A pragmatic approach to assessing risks from climate variability and change — A case study in Mozambique, 19, 74-88. doi:10.1016/j.gloenvcha.2008.11.002.

Kay, R. C., \& Alder, J. (2005). Coastal planning and management. London: E\&F Spon.

Liu, Z., \& Liu, L. (2016). Characteristics and driving factors of rural livelihood transition in the east coastal region of China: A case study of suburban Shanghai. Journal of Rural Studies, 43, 145-158. doi:10.1016/j.jrurstud.2015.12.008.

Marfai, M. A. (2003). GIS modelling of river and tidal flood hazards in a waterfront city (Case Study: Semarang City, Central Java, Indonesia). ITC: The Netherlands.

Mileti, D. S., \& Peek-Gottschlich, L. (2001). Hazards and sustainable development in the United States. Risk Management, 3(1), 61-70. doi:10.1057/palgrave.rm.8240077.

Nelson, K. S., Abkowitz, M. D., \& Camp, J. V. (2015). A method for creating high resolution maps of social vulnerability in the context of environmental hazards. Applied Geography, 63, 89-100. doi:10.1016/j.apgeog.2015.06.011. 


\section{Kerentanan Sosio-Ekonomi terhadap Paparan Banjir dan Rob di Pedesaan Pesisir Kabupaten Demak}

Nguyen, T. T. X., Bonetti, J., Rogers, K., \& Woodroffe, C. D. (2016). Indicator-based assessment of climatechange impacts on coasts: A review of concepts, methodological approaches and vulnerability indices. Ocean and Coastal Management, 123, 18-43. doi:10.1016/j.ocecoaman.2015.11.022.

Osbahr, H., Twyman, C., Adger, W. N., \& Thomas, D. S. G. (2008). Effective livelihood adaptation to climate change disturbance: Scale dimensions of practice in Mozambique. Geoforum, 396), 1951-1964. doi:10.1016/j.geoforum.2008.07.010.

Shah, K. U., Dulal, H. B., Johnson, C., \& Baptiste, A. (2013). Understanding livelihood vulnerability to climate change: Applying the livelihood vulnerability index in Trinidad and Tobago. Geoforum, 47, 125-137. doi:10.1016/j.geoforum.2013.04.004.

Sunarto \& Rahayu, L. (2006). Fenomena Bencana Alam di Indonesia. Jurnal Kebencanaan Indonesia, 1(1), 1-5. 